ACTA MYCOLOGICA

Vol. 41 (1): 65-72

2006
Dedicated to Professor Alina Skirgietto

on the occasion of her ninety fifth birthday

\title{
Some additional Laboulbeniales (Ascomycetes) new to Poland
}

\author{
TOMASZ MAJEWSKI \\ Department of Plant Pathology, Warsaw Agricultural University \\ Nowoursynowska 166, PL 02787 Warszawa \\ tomasz_majewski@sggw.pl
}

Majewski T.: Some additional Laboulbeniales (Ascomycetes) new to Poland. Acta Mycol. 41(1): 65 72, 2006.

Six fungal species belonging to the order Laboulbeniales new to Poland are described and illustrated: Dimeromyces corynetis Thaxter, Euphoriomyces magnicellulatus Santamaria, Laboulbenia cornuta Thaxter, L. manubriolata Thaxter, L. nana Sugiyama and L. olisthopi Spegazzini. The status of the latter species, also reported from Ukraine, is briefly discussed.

Key words: Laboulbeniales, Dimeromyces, Euphoriomyces, Laboulbenia, Poland, Ukraine

\section{INTRODUCTION}

Six species of the order Laboulbeniales new to Poland are described and illustrated. Recorded only recently, they are not listed in the author's previous publications (Majewski 1994, 1999). Two species were collected during field studies ( $\mathrm{L} a$ boulbenia cornuta and L. manubriolata). The others were identified on insects in the following entomological collections: private collection of Roman Królik, Kluczbork (Dimeromyces corynetis), private collection of Rafał Ruta, Piła (Euphoriomyces magnicellulatus), collection of the Museum and Institute of Zoology, Polish Academy of Sciences, Łomna (Laboulbenia nana), and the Natural History Museum, Institute of Systematics and Evolution of Animals, Polish Academy of Sciences, Kraków (Laboulbenia olisthopi).

Additionally, Laboulbenia elaphricola J.Siemaszko et W.Siemaszko should also be classified in the mycoflora of Poland. The species was considered to be a synonym of Laboulbenia elaphri Spegazzini by the author (Majewski 1994). De Kesel and Krastina-De Kesel (2006), however, have now confirmed specific distinctness of Laboulbenia elaphricola. A total of 206 species of the order Laboulbeniales are now known from Poland. They are presented in a forthcoming publication (Majew ski ms.) which provides a full list of references and the descriptions of the localities in Poland. 
Aknowlogments. The author would like to thank Mr Roman Królik and Mr Rafał Ruta as well as the collection curators in Łomna and Kraków, Dr. Violetta To maszewska and Dr. Daniel Kub is z, for kindly providing insects for examination. The specimens listed in this study are in the author's collection which will be handed over to the herbarium of the Institute of Botany, Polish Academy of Sciences.

\section{DESCRIPTIONS OF SPECIES}

\section{Dimeromyces corynetis Thaxter}

Dimeromyces corynetis Thaxter, Proc. Amer. Acad. Arts 48: 157. 1912 ('D. Corynitis').

Female thallus yellowish, $290 \mu \mathrm{m}$ long. Receptacle $50 \mu \mathrm{m}$ long (without the foot), consisting of four cells; the basal cell large, elongated, the second one flattened, bearing laterally a short, slender secondary appendage; the third cell isodiametric, bearing laterally the perithecium, and the fourth cell isodiametric, bearing laterally a long, slender, 6-celled secondary appendage. Primary appendage being a continuation of the receptacle axis, unicellular, elongated, as long as the basal cell of the receptacle. Perithecium fusiform, $175 \times 45 \mu \mathrm{m}$, with indistinct neck, stalk cell $75 \mu \mathrm{m}$ long. Male thallus not found (Fig. 1a).

On Necrobia ruficollis (Fabricius) (Coleoptera, Cleridae): Wierzbica Górna, Kluczbork poviat, ex cadaver of Capreolus capreolus (L.), leg. Roman Królik, 28.8.1990, TM 10100 (host ex coll. R. Królik).

Only one complete thallus was found on the host's elytron. Its features are consistent with the descriptions and figures given by Thaxter (1924) and S a n t a mari a (2003). Dimeromyces corynetis, an infrequent species, parasitizes representatives of the genera Corynetes and Necrobia. It is known from America (Argentina and Hawaii) and from Western Europe, namely from Spain, Great Britain, France, and Italy (S ant a maria et al. 1991; S anta maria 2003).

Euphoriomyces magnicellulatus Santamaria

Euphoriomyces magnicellulatus Santamaria, Revista Iberoam. Micol. 8: 48. 1991.

Thallus hyaline, 85-135 $\mu \mathrm{m}$ long. Receptacle consisting of 6-8 superposed cells, $40-63 \mu \mathrm{m}$ long. The basal cell usually somewhat elongated, the remaining cells rather flattened in the lower part of the receptacle and isodiametric in its upper part. Except the basal one, the receptacle cells cut off bilaterally basal cells of short secondary antheridial blanchlets or stalk cells of perithecia. Primary appendage is a prolongation of the receptacle, not exceeding the perithecial apex. It consists of one or two cells bearing antheridia laterally and distally. Perithecia one or two per thallus, 50-75 $\mathrm{x}$ 18-25 $\mu \mathrm{m}$, elongated, broadest near the middle, with indistinct neck. Fig. 1: b-e.

On Hydnobius multistriatus (Gyllenhall) (Coleoptera, Leiodidae): Pieskowa Skała, Kraków poviat, 18.8.2001, leg. Rafał Ruta, TM 10512-10514 (host ex coll. R. Ruta).

Many thalli were found on the elytra of one insect in an entomological collection. They are mostly consistent with the description given by S a $\mathrm{t}$ a m a ria $(1991,2003)$; however, thalli with two mature or maturing perithecia are frequent.

Euphoriomyces magnicellulatus seems to be a very rare species. It has been reported only from Spain on Hydnobius spinipes (Gyllenhal) (type host), Leiodes sp. and Baptolinus affinis (Paykull), and from the Balearic Islands on Hydnobius sp. 


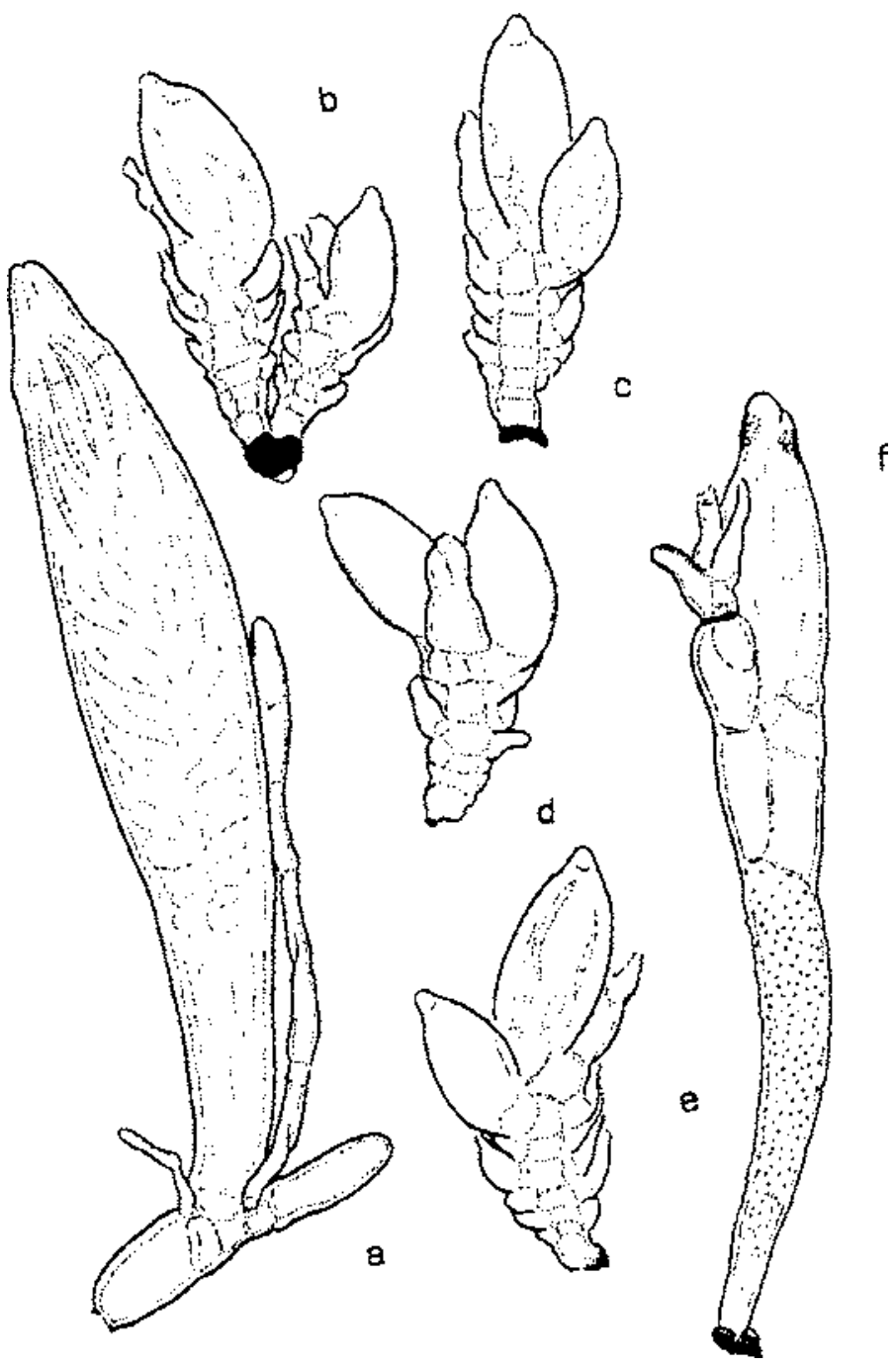

Fig. 1. Dimeromyces corynetis Thaxter. a female thallus (drawn from TM. 10100). Eupho riomyces magnicellulatus Santamaria. b paired thalli with one perithecium (TM 10513), c e thalli with two perithecia (TM 10514). Laboulbenia manubriolata Thaxter. f mature thallus (TM 10161). Scale bar: $100 \mu \mathrm{m}$. 
(Santamaria 1991, 2003). The above hosts belong to the family Leiodidae. The Polish host, Hydnobius multistriatus, is a rare species, and its lifestyle and ecological preferences are not known (Burakowski et al. 1978).

\section{Laboulbenia cornuta Thaxter}

Laboulbenia cornuta Thaxter, Proc. Amer. Acad. Arts Sci. 30: 476. 1895.

Thalli similar to those of Laboulbenia luxurians (see Majewski 1994). Their particularly characteristic features include flattened cell III situated obliquely, large cell V, and hyaline, short anterior appendage branchlets directed towards the perithecium. $L$. cornuta differs from $L$. luxurians in having larger and almost isodiametric basal cells of appendage as well as a unicellular straight horn on the perithecial apex directed anteriorly. Thalli 192-220 $\mu \mathrm{m}$ long (including horn), receptacle 105-120 um long, perithecium (without horn) 88-95 x 38-48 $\mu$ m (Fig. 2 a, b).

On Bembidion obliquum (Sturm) (Coleoptera, Carabidae, subgenus Notaphus): Zielona Góra: Jędrzychów, sand by the water on the bottom of a large sand pit surrounded by a Pinus sylvestris $\mathrm{L}$. forest by the S town border, 14.8.2002, leg. T. Majewski, TM 9420.

The thalli of $L$. cornuta discussed here are consistent with Thaxter's description $(1895,1896)$ and figures given by Thaxter (1896) and S a n t a maria (2001).

Laboulbenia cornuta is a rare species. It was described from the U.S.A. (Th axt e r 1895), and was later reported from Cuba (Balazuc 1977), Hungary (Bánhegyi 1944) and Spain (Santamaria 2001). Hosts are beetles of the genus Bembidion sensu lato belonging to the subgenus Notaphus Stephens, which is often considered to be a separate genus in the entomological literature.

\section{Laboulbenia manubriolata Thaxter}

Laboulbenia manubriolata Thaxter, Proc. Amer. Acad. Arts Sci. 51: 44. 1915.

Thallus yellowish, slender, $245 \mu \mathrm{m}$ long. Cells I, II, III and IV elongated, cell V half as long as cell IV. Cell wall of cell II and upper half of cell I distinctly tuberculate, somewhat darker than the other part of the thallus. Insertion cell thin, constricted. The outer basal cell of appendage forming blunt outgrowth, appendage branchlets not preserved in the described thallus. Cells VI and VII elongated, perithecium $75 \mathrm{x}$ $28 \mu \mathrm{m}$, subfusiform, more than one half free, with indistinct neck. Fig. 1f.

On Perigona nigriceps (Dejean) (Coleoptera, Carabidae): Branice, Głubczyce poviat, pile of old hay surrounded by nettles (Urtica dioica $\mathrm{L}$.) on the border of a meadow and a cluster of trees (Salix fragilis L.) near the Opawica river ca. $1 \mathrm{~km}$ SWW of the village, 15.7.2004, leg. T. Majewski, TM 10161.

Laboulbenia manubriolata was described by Thaxter (1915) from Java and Ceylon and reported again from China by Rossi (1982), who was the first to provide a picture of it. It was later recorded in a number of countries in eastern Asia (Te ra d a et al. 2004). It seems to occur mostly on Perigona nigriceps in Asia. This beetle has also been encountered in Europe, introduced here sporadically with plant material. Its parasite, L. manubriolata, has been reported from Portugal (S a n ta maria 1993), Great Britain (Weir 1996), Finland (Huldén 1983) and Norway (Huldén 1985). Perigona nigriceps is found in Poland very rarely (Burakowski et al. 1974 Jałoszyński, Sienkiewicz 2002). 


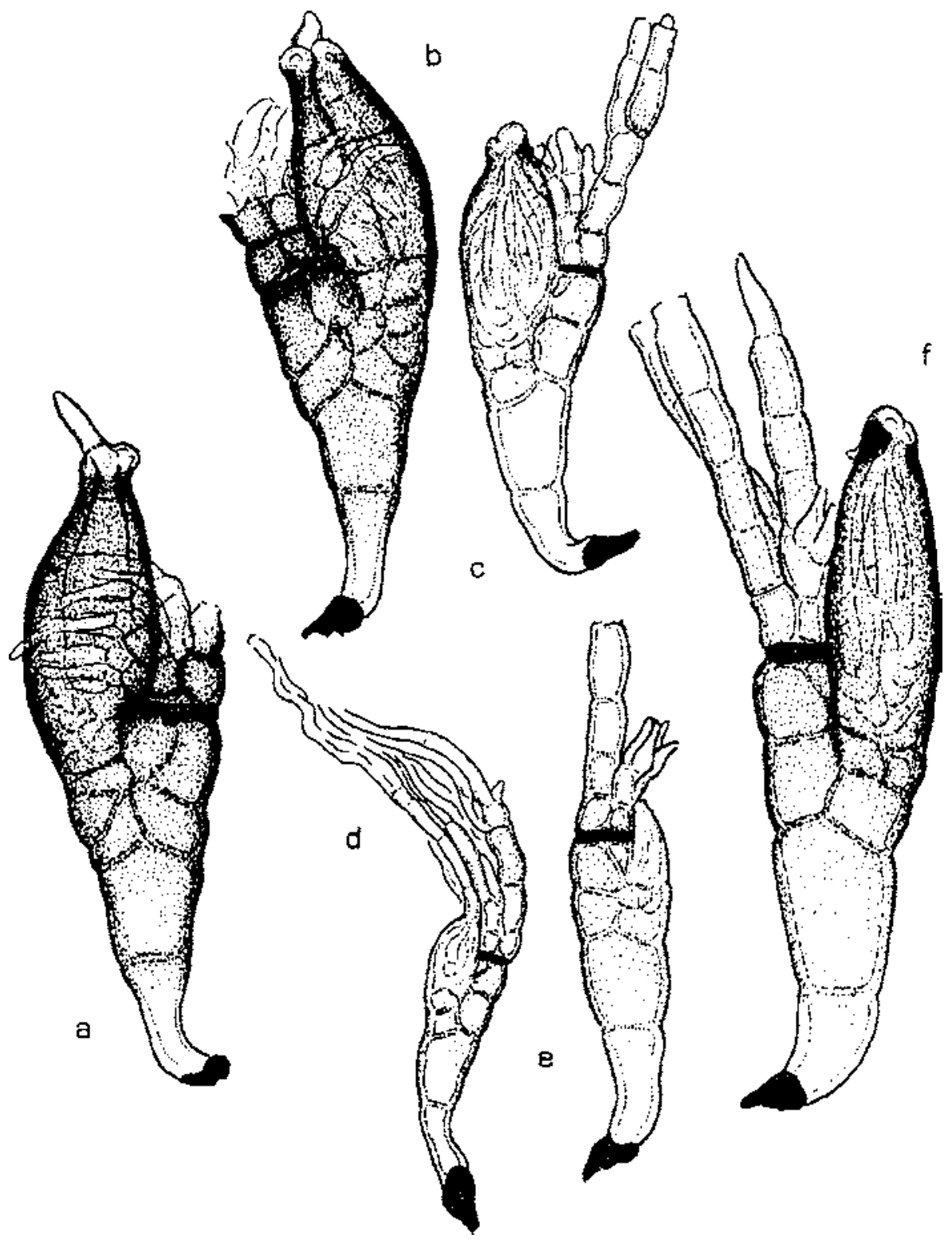

Fig. 2. Laboulbenia cornuta Thaxter. a, b mature thalli (drawn from TM 9420). Laboulbenia nana Thaxter. c mature thallus (TM 10617), d immature thallus (TM 10618). Laboulbe nia olisthopi Spegazzini. e immature thallus (TM 10099), f mature thallus (TM 10098). Scale bar: $100 \mu \mathrm{m}$. 
The features of the only thallus collected in Poland are consistent with the descriptions and figures given by, inter alia, Rossi (1982), S antamaria (1993) and Terada (2000).

\section{Laboulbenia nana Sugiyama}

Laboulbenia nana Sugiyama, Ginkgoana 2: 54. 1973.

Thallus 150-155 $\mu \mathrm{m}$ long, olive-brownish, perithecial region darkened. Receptacle 78-108 $\mu \mathrm{m}$ long, curved near the base. Cells I and II 2-3 times longer than broad, cells III and IV 1.5 times longer than broad, cell V half as long as cell IV. Insertion cell dark, slightly constricted; outer appendage long, composed of elongated cells, once branched on second (?) or third cell; basal cell of inner appendage only slightly shorter than basal cell of outer appendage, antheridial branchlets not exceeding the perithecium, but some antheridia may proliferate into longer branchlets. Stalk cell of the perithecium oblique, isodiametric or slightly flattened; perithecium ovate, 70$74 \times 25-30 \mu \mathrm{m}$, about $2 / 3$ free, with apical dark spots and prominent round posterior lips (Fig. 2: c, d.).

On Tachyta nana (Gyllenhal) (Coleoptera, Carabidae): Rytro, Nowy Sącz poviat, under the bark of Fagus sylvatica L. 28.7.1929, ex coll. Szymon Ten en b a um, TM 10617, 19618 (host in the Łomna collection).

Laboulbenia nana seems to be a very rare species. It was described from Japan by Sugiya ma (1973), later reported only from Spain (S a n ta maria 1995, 1998); it may also occur in Romania (S a t t m m ri a 1998). In Poland, it has been recorded only on two insects in an old entomological collection. Only two mature thalli and two immature thalli growing on the host's elytron and pronotum were recorded. The thalli are not well preserved, especially appendages; they are, however, consistent with the descriptions and figures given in the above studies by Su giy a m a and S a nt a m a ria. The host is a tiny beetle, fairly often encountered under the bark of dead trees in Poland (Burakowski et al. 1973).

\section{Laboulbenia olisthopi Spegazzini}

Laboulbenia olisthopi Spegazzini, Redia 10: 55.1914 ('L. olistopi').

Thallus 190-265 $\mu \mathrm{m}$ long, brownish, perithecial region and upper part of receptacle darkened. Receptacle 140-177 $\mu \mathrm{m}$ long, cell I 1.5 times longer than broad in its distal part, cell II 2 times longer than broad, cells III and IV nearly isodiametric, cell V half as long as cell IV or slightly longer. Insertion cell dark, thick, distinctly constricted; outer appendage long, consisting of elongated cells; basal cell of inner appendage more than half as long as basal cell of the outer one, giving rise to two short antheridial branchlets later proliferating into two strong straight long branches. Basal cell of perithecium oblique, rhomboidal, the perithecium 95-130 x 38-45 $\mu \mathrm{m}$, in $2 / 3$ free, nearly ovate; apex with prominent posterior lips and distinct subapical black spots (Fig. 2: e, f.).

On Olisthopus sturmii (Duftschmid) (Coleoptera, Carabidae): vicinity of Przemyśl, leg. Tadeusz Trella, no date [before 1940], TM 10099. Additional material from Ukraine: on O. sturmii, Chliwiska, Sniatyn poviat, 6.10.1886, leg. Stanisław Stobiecki, TM 10098 (both hosts in the Kraków collection).

The described material comprises 3 immature thalli recovered from the host's elytron in Poland as well as 6 mature thalli and 3 immature thalli growing on a beetle collected in western Ukraine. The determination of the thalli is provisional. 
Laboulbenia olisthopi has been collected across Europe (Spain, France, Germany, Italy, Switzerland, Madeira); only three authors, however, described and illustrated it. The first, Spegazzini (1914), gives a brief description and somewhat blurred photographs of an immature thallus and three mature thalli, strongly darkened. It seems that cell $\mathrm{V}$ is triangular in these thalli, smaller than cell IV and probably is not connected with septum III/IV. Spegazzin i's specimens were collected in Italy on Olisthopus rotundatus (Paykull) and in Germany (Saxonia) on O. sturmii. Balazuc (1975) lists all species of the genus Laboulbenia recorded on beetles of the genus Olisthopus Dejean (Odontonyx Stephens) up to the time of his study: Laboulbenia polyphaga Th., Laboulbenia olisthopi Speg. and Laboulbenia flagellata Peyr. He identifies Olithopus sturmii as the type host of the species described by Spegazzini, and describes and illustrates the thalli of Laboulbenia olisthopi found in France on Odontonyx rotundatus (Olisthopus rotundatus) and Madeira on $O$. fuscatus Dejean. Cell V in these specimens is nearly as large as cell IV and is distinctly connected with septum between cells III and IV.

Sant a maria (1989) describes thalli from Spain on Olisthopus fuscatus Dejean. Their cells IV and V are subequal, as in Balazuc's thalli. Similar findings are provided in Santamaria's successive study (1998): the description and figures show cell V to be as long as cell IV. S a n t a m a ri concludes that septum IV/V connected with septum III/IV is an essential character to separate L. olisthopi and forms surrounding L. polyphaga Thaxter.

Undoubtedly, the Polish (and Ukrainian) thalli collected on Olisthopus sturmii and described here belong to a species different from the thalli discussed by Balazuc and Santamaria, and are likely to be closer to Spegazzini's species. Additionally, the host of the present material, Olithopus sturmii, is the same host as the one recognised as the type host of L. olisthopi, and the collection site of the type specimen (Saxony) is located near Poland. „L. olisthopi” thalli visible in the pictures given by Balazuc and Santamaria come from different hosts and areas situated further away from the present sites. It should be noticed that the thalli determined here as L. olisthopi differ significantly from the thalli of Laboulbenia polyphaga recorded in Poland (Majews ki 1994) in being clearly darker, and the outer branch of their appendage is not forked.

The Polish host, Olisthopus sturmii, is a xerothermic species, found rarely in the south of Poland (Burakows ki et al. 1974).

\section{REFERENCES}

Balazu c J. 1975. Sur les Laboulbenia (Ascomycètes) parasites d'Odontonyx (Coleoptera Caraboidea, Pterostichidae, Anchomenini). Nouv. Rev. Ent. 5: 97100.

Ba lazu c J. 1977. Deuxième mission biospéologique cubano roumaine à Cuba (1973). Laboulbéniales (Ascomycètes) parasites de Coléoptères Carabiques. (In:) T. Orghidan et al. (eds). Résultats des exspéditions biospéologiques cubano roumaines à Cuba, vol. 2, Bucureşti: 413415.

Bánhegyi J. 1944. A Balaton környékének Laboulbenia féléi. Botan. Közlem. 41 : 49 61, Pl. I II.

Burakowski B., Mroczkowski M., Stefańska J. 1973. Coleoptera, Carabidae 1, (In:) Katalog fauny Polski (Catalogus faunae Poloniae) 20, PWN, Warszawa, pp. 233.

Burakowski B., Mroczkowski M., Stefańska J. 1974. Coleoptera, Carabidae 2, (In:) Katalog fauny Polski (Catalogus faunae Poloniae) 22, PWN, Warszawa, pp. 430.

Burakowski B., Mroczkowski M., Stefańska J. 1978. Coleoptera, Histeroidea, Staphylinoidea excl. Staphylinidae. (In:) Katalog fauny Polski (Catalogus faunae Poloniae) 29, PWN, Warszawa, pp. 356. 
De Kesel A., Krastina De Kesel I. 2006. Laboulbeniales (Ascomycetes) from Latvia. Acta My col. 41(1): 5564.

Huldén L. 1983. Laboulbeniales (Ascomycetes) of Finland and adjacent parts of the U.S.S.R. Karstenia 23: 31136.

Huldén L. 1985. Floristic notes on Palearctic Laboulbeniales (Ascomycetes). Karstenia 25: 116.

J ałoszyńs ki P., Sien ki ewicz P. 2002. The second record of Perigona nigriceps (Dejean, 1831) (Cole optera: Carabidae) from Poland. Wiad. Entomol. 20: 173.

Majewski T. 1994. The Laboulbeniales of Poland. Polish Bot. Stud. 7: 3466.

Majewski T. 1999. New and rare Laboulbeniales (Ascomycetes) from the Białowieża Forest (NE Po land). Acta Mycol. 34: 739.

Majewski T., in press. Laboulbeniales, (In:) W. Wojewoda (ed.), Atlas of the geographical distribu tion of fungi in Poland. Fasc. 4. Institute of Botany, Polish Acad. of Sciences, Kraków.

Rossi W. 1982. New and interesting Laboulbeniales from China. Mycologia 74: 10231026.

S a n t a mari a S. 1989. El orden Laboulbeniales (Fungi, Ascomycotina) en la Peninsula Ibérica e Islas Baleares. Ed. Espec. Soc. Catalana Micol. 3, Barcelona, pp. 396.

S a nt a mari a S. 1991. El género Euphoriomyces (Laboulbeniales, Ascomycotina). Revista Iberoamer. Micol. 8: 4350.

Santamaria S. 1993. Contribución al conocimiento de los Laboulbeniales (Fungi, Ascomycotina) ibéricos, III. Orsis 8: 2131.

Santamaria S. 1995. New and interesting Laboulbeniales (Fungi, Ascomycotina) from Spain, III. Nova Hedwigia 61: 6583.

S a nt a mari a S. 1998. Laboulbeniales, I. Laboulbenia. Flora Mycologica Iberica 4, J. Cramer, Madrid, Berlin, Stuttgart, 186 pp.

S a n t a m a ri a S. 2001. New and interesting Laboulbeniales (Fungi, Ascomycota) from Spain, IV. Nova Hedwigia 72: 375389 .

Santamaria S. 2003. Laboulbeniales, II. Acompsomyces Ilyomyces. Flora Mycologica Iberica 5, J. Cramer, Madrid, Berlin, Stuttgart, 344 pp.

S an t a mari a S., B a la zu c J., Tava re s I.I. 1991. Distribution of the European Laboulbeniales (Fungi, Ascomycotina). An annotated list of species. Treballs Inst. Botan. Barcelona 14: 1123.

Spegazzini C. 1914. Primo contributi alla conoscenza delle Laboulbeniali italiane. Redia 10: 21 75, Pl. I IX.

Sugiy a m K K. 1973. Species and genera of the Laboulbeniales (Ascomycetes) in Japan. Ginkgoana 2: 1 97, Pl. 1127.

Terada K. 2000. New records of the carabidicolous Laboulbeniales (Ascomycetes) of Japan (II). My coscience 41: 3948 .

Te ra d a K., M. H. Hsu, W. J. Wu. 2004. Notes on the carabidicolous Laboulbeniales (Ascomycetes) of Taiwan I. Botan. Bull. Acad. Sinica 45: 8794.

Thaxter R. 1895. Notes on the Laboulbeniaceae, with descriptions of new species. Proc. Amer. Acad. Arts Sci. 30: 467481.

Th axter R. 1896. Contribution towards a monograph of the Laboulbeniaceae. Mem. Amer. Acad. Arts Sci. 12: 187 429, Pl. I XXVI.

Thaxter R. 1915. New Indo Malayan Laboulbeniales. Proc. Amer. Acad. Arts Sci. $51: 351$.

Thaxter R. 1924. Contribution towards a monograph of the Laboulbeniaceae. Part III. Mem. Amer. Acad. Arts Sci. 14: 309 426, Pl. I XXII.

Weir A. 1996. A preliminary host parasite list of British Laboulbeniales (Fungi, Ascomycotina). The Entomologist 115: 5058.

\section{Nowe dla Polski gatunki Laboulbeniales (Ascomycetes)}

\section{Streszczenie}

Praca zawiera opisy i ryciny sześciu nowych dla Polski gatunków grzybów z rzędu Laboul beniales: Dimeromyces corynetis Thaxter, Euphoriomyces magnicellulatus Santamaria, Laboul benia cornuta Thaxter, L. manubriolata Thaxter, L. nana Sugiyama i L. olisthopi Spegazzini. Ostatni z nich wykazany został także z Ukrainy; dyskutowany jest jego status. 